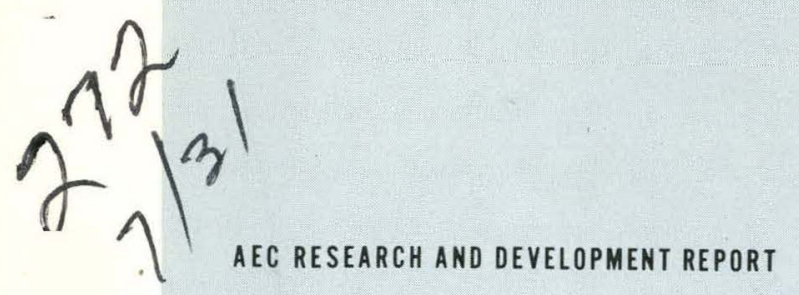

\title{
MORTALITY EXPERIENCE OF URANIUM AND NONURANIUM WORKERS
}
L. M. Scott
K. W. Bahler
A. de la Garza
T. A. Lincoln, M. D.

\section{UNION CAREIDE CORPORATION NUCLEAR DIVISION OAK RIDGE Y-12 PLANT}

operated for the ATOMIC ENERGY COMMISSION under U. S. GOVERNMENT Contract W-7405 eng 26 


\section{DISCLAIMER}

This report was prepared as an account of work sponsored by an agency of the United States Government. Neither the United States Government nor any agency Thereof, nor any of their employees, makes any warranty, express or implied, or assumes any legal liability or responsibility for the accuracy, completeness, or usefulness of any information, apparatus, product, or process disclosed, or represents that its use would not infringe privately owned rights. Reference herein to any specific commercial product, process, or service by trade name, trademark, manufacturer, or otherwise does not necessarily constitute or imply its endorsement, recommendation, or favoring by the United States Government or any agency thereof. The views and opinions of authors expressed herein do not necessarily state or reflect those of the United States Government or any agency thereof. 


\section{DISCLAIMER}

Portions of this document may be illegible in electronic image products. Images are produced from the best available original document. 
Printed in the United States of America. Available from Clearinghouse for Federal Scientific and Technical Information, National Bureau of Standards,

U.S. Department of Commerce, Springfield, Virginia 22151

Price: Printed Copy $\$ 3.00$; Microfiche $\$ 0.65$

\section{LEGAL NOTICE}

This report was prepared as an account of Government sponsored work. Neither the United States, nor the Commission, nor any person acting on behalf of the Commission:

A. Makes any warranty or representation, expressed or implied, with respect to the accuracy, completeness, or usefulness of the information contained in this report, or that the use of any information, apparatus, method, or process disclosed in this report may not infringe privately owned rights; or

B. Assumes any liabilities with respect to the use of, or for damages resulting from the use of any information, apparatus, method, or process disclosed in this report.

As used in the above, "person acting on behalf of the Commission" includes any employee or contractor of the Commission, or employee of such contractor, to the extent that such employee or contractor of the Commission, or employee of such contractor prepares, disseminates, or provides access to, any information pursuant to his employment or contract with the Commission, or his employment with such contractor. 


\title{
UNION CARBIDE CORPORATION Nuclear Division
}

\author{
OAK RIDGE Y-12 PLANT
}

Operated under Contract W-7405-eng-26

With the US Atomic Energy Commission

\section{MORTALITY EXPERIENCE OF URANIUM AND NONURANIUM WORKERS}

\author{
L.M. Scott \\ K. W. Bahler \\ A. de la Garza \\ T. A. Lincoln, M.D.
}

This report WA: NOTICE

sponsored by the urepared as an account of work

the United States nor the States Government. Neither Commission, nor any of United States Atomic Energy their contractors, any of their employees, nor any of makes any warranty, subcontractors, or their employees, legal liability or nty, express or implied, or assumes any pegal liability .or responsibility for the or assumes any pleteness or usefulness of any for the accuracy, comproduct or process disclosed -information, apparatus, would not infringe privately, or represents that its use Wuld not infringe privately owned rights.

Ouk Ridge, Teimessee 


\section{DISTRIBUTION}

\section{Atomic Energy Commission}

Keller, C. A.

Zachry, D. S.; Jr

Oak Ridge Gaseous Diffusion Plant

Jordan, R. G.

Wilcox, W. J., Jr

Oak Ridge National Laboratory

Lincoln, T. A.

Oak Ridge Y-12 Plant

Bahler, K.W.

Ballenger, H. F. (2)

Beeson, H. C.

Bell, B. B.

Bernander, N. K.

Briscoe, O:W.

Burkhart, L. E.

Butturini, W. G.

Choat, E. E.

de la Garza, A.

Ebert, J.W.
Ellingson, R. D.

Evans, G.W. Gritzner, V. B. Haeusler, K. R. Hemphill, L. F. Hensley, C. E. Hill, D. G. Johnson, C. E. Keith, Alvin McLendon, J. D. Mitchel, G. W. Scott, L. M. (10) Smith, H. F:, Jr Smith, R. D. Snyder, H. G. P. Trotter, T.C. Waters, J. L. Wesley, R. L. Yaggi, W. J. Y-12 Central Files (5) $Y-12$ Central Files (route) $Y-12$ Central Files ( $Y-12 R C)$

Paducah Gaseous Diffusion Plant

Winkel, R. A.

In addition, this report is distributed in accordance with the category Health and Safety, as given in the "USAEC Standard Distribution Lists for Unclassified Scientific and Technical Reports", TID-4500. 


\section{ABSTRACT}

A study was made of mortality rates of uranium and nonuranium workers in two facilities processing massive quantities of uranium. The uranium worker group consisted of over 4,500 employees with a total of about 14,000 man-years of association with uranium processing.

It was concluded that the mortality experience was more favorable for the uranium workers than for the nonuranium workers in the same plants during the same period. 


\section{CONTENTS}

MORTALITY EXPERIENCE OF URANIUM AND NONURANIUM WORKERS. .................. 5

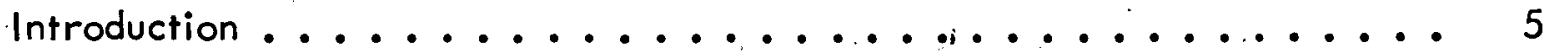

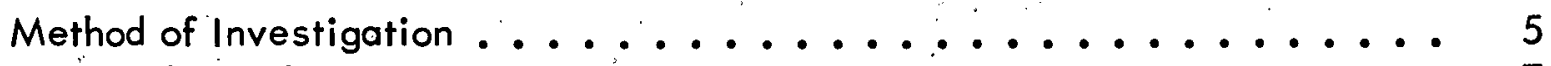

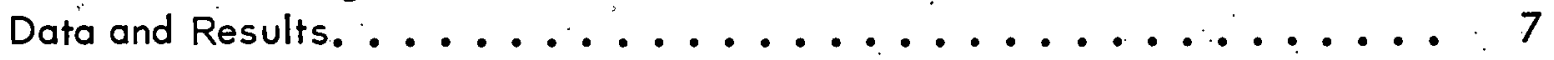

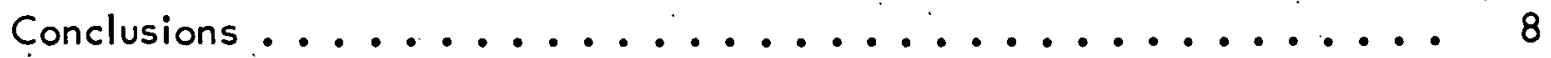

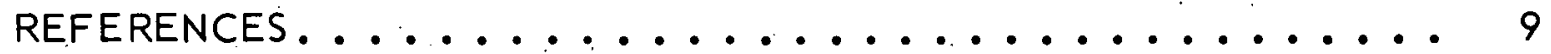

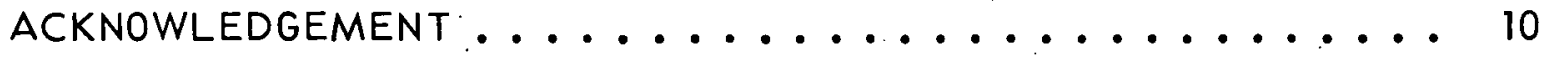

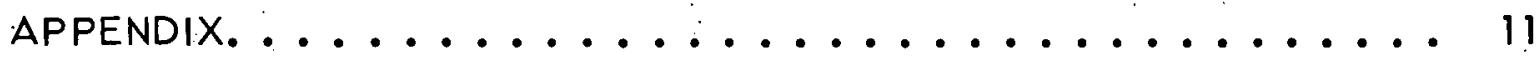




\section{MORTALITY EXPERIENCE OF URANIUM AND NONURANIUM WORKERS}

\section{INTRODUCTION}

With the growing nationwide interest in pollution, increased attention is being focused on a variety of employee exposures to industrial pollutants. One of these, uranium, is of particular interest to managers of nuclear industries.

The Oak Ridge Gaseous Diffusion and $Y-12$ Plants (a) have been processing uranium on a massive scale for over 25 years. Careful attention has been given to personnel protection, and environmental concentrations of uranium at these installations have generally been maintained well below established safety criteria. Nevertheless, questions are raised periodically concerning the effect of uranium work on employees.

Because of the dearth of published human data on this subject, maximum permissible concentration guides are based primarily on animal studies. The data available in these facilities offer a unique opportunity for evaluating the effect of uranium work on a large population of employees over an extended period. The study is an attempt to utilize human data in objectively assessing practices in one segment of the uranium business.

An earlier study(1) found that during the period from 1950 through 1965, Union Carbide Corporation employees in the Oak Ridge atomic energy facilities experienced fewer deaths than would be expected based on the mortality tables published by the Bureau of Vital Statistics. This new study presents results of a comparison of the mortality experience of uranium and nonuranium workers in two Oak Ridge nuclear energy facilities.

\section{METHOD OF INVESTIGATION}

The population used in this study comprises essentially all employees at the Oak Ridge Gaseous Diffusion and $Y-12$ Plants who were hired after December 31, 1950. Thus, the study covered a time period of 19 years (from January 1, 1951 through December 31, 1969).

This population was divided into two logical groups, uranium workers and nonuranium workers. During the study period, all employees who regularly

(a) Operated by Union Carbide Corporation's Nuclear Division for the US Atomic Energy Commission. 
worked in uranium processing areas submitted routine urine samples for uranium analysis. Utilizing these uranium urine analysis data, the employees who worked in uranium processing areas could be readily identified. This "uranium" group consisted primarily of technicians and craftsmen, but also included some administrative and professional employees. Only employees who never submitted a urine sample under this program were considered as the nonuranium workers. This "nonuranium" group is made up of a broad spectrum of employee classifications: technicians, administrators, professionals, secretaries, and craftsmen. Those employees who had submitted a few infrequent urine samples were not included in the study because they did not clearly fit into either group.

From a list of former employees the Social Security Administration identified those persons. who were deceased. Starting date of the study was dictated by the ready availability of data from this source.

Direct comparison of the mortality experience of uranium and nonuranium workers was not appropriate because the groups differ in proportionality by sex, age, and race. The best alternate to a direct comparison was to compare the ratio of the number of actual deaths to a calculated expected number of deaths for each group. Using a mortality table from the Bureau of Vital Statistics (BVS), (2) expected deaths were calculated. This table was selected for two reasons: (1) the same table was used in the previously referenced study, and by using it in this study, a check could be made on the conclusions drawn previously; and (2) the mortality experience reflected by the BVS table is between that of annunity $(3)$ and insurance $(4)$ tables. Variance in mortality tables is well recognized by actuaries and described by McGill(5) in his insurance text as follows:

"All mortality tables, of course, contain a margin for safety-which, in the case of life insurance mortality tables, means higher death rates than those which are likely to be experienced and, in the case of annuity mortality tables, means lower rates of mortality than those anticipated".

As explained later, calculations show that in comparing mortality experience the choice of mortality tables has essentially no effect if the same table is used for both work groups. It is emphasized that the purpose of using mortality table information to establish expected deaths is merely to develop consistent statistics for comparison of mortality in two groups. The mortality table is not used as a predictor for an absolute number of deaths in either group.

The BVS mortality tables are constructed so that knowing age at the start of a period of interest, plus race and sex, one can determine the probability 
of death for an individual over any time period. For this study, the period of interest for each nonuranium worker was between his hire-in date and December 31, 1969; for a uranium worker the period of interest was between the date of submission of the first urine sample and December 31, 1969. Therefore, with the age of an individual at the start of the time period, and the length of the period, values were read out of the table for the proper sex and race to indicate the probability of death for that individual. The number of expected deaths in a group was then obtained by adding expected deaths for all workers in that specific group. A sample calculation is shown in the Appendix.

Since some uranium workers were not involved with uranium immediately upon hire, expected deaths for this group, prior to entry into a uranium assignment, were included in the expected deaths of nonuranium workers.

\section{DATA AND RESULTS}

Table 1 reports the data for the population of uranium and nonuranium workers by plant and sex. Although race was used in determining the expected deaths, race is not shown in the table due to the relatively small number of blacks.

Table 1

POPULATION OF WORKERS IN MORTALITY STUDY

\begin{tabular}{|c|c|c|c|c|c|}
\hline \multirow[b]{2}{*}{ Worker Group } & \multicolumn{2}{|c|}{ Deoths } & \multirow{2}{*}{$\begin{array}{c}\text { Average } \\
\text { Age on } \\
12 / 31 / 69\end{array}$} & \multirow[b]{2}{*}{ Man-Yeors (2) } & \multirow{2}{*}{$\begin{array}{c}\text { Number } \\
\text { in } \\
\text { Group }\end{array}$} \\
\hline & Actual & Expected (1) & & & \\
\hline \multicolumn{6}{|l|}{ ORGDP } \\
\hline $\begin{array}{l}\text { Uranium Workers } \\
\text { Mole } \\
\text { Female }\end{array}$ & $\begin{array}{r}44 \\
0\end{array}$ & $\begin{array}{r}75 \\
3\end{array}$ & $\begin{array}{l}4 \\
45.7 \\
42.1\end{array}$ & $\begin{array}{r}2,760 \\
\quad 120\end{array}$ & $\begin{array}{r}1,178 \\
116\end{array}$ \\
\hline $\begin{array}{l}\text { Nonuranium Worke } \\
\text { Mole } \\
\text { Female }\end{array}$ & $\begin{array}{l}93 \\
11\end{array}$ & $\begin{array}{r}127 \\
16\end{array}$ & $\begin{array}{l}38.3 \\
37.0\end{array}$ & $\begin{array}{l}7,420 \\
2,910\end{array}$ & $\begin{array}{r}2,851 \\
885\end{array}$ \\
\hline$Y-12$ & & & & & \\
\hline $\begin{array}{l}\text { Uranium Worters } \\
\text { Male } \\
\text { Female }\end{array}$ & $\begin{array}{r}89 \\
1\end{array}$ & $\begin{array}{r}148 \\
3\end{array}$ & $\begin{array}{l}44.2 \\
43.3\end{array}$ & $\begin{array}{r}10,810 \\
540\end{array}$ & $\begin{array}{r}3,150 \\
109\end{array}$ \\
\hline $\begin{array}{l}\text { Nonuranium Worke } \\
\text { Male } \\
\text { Female }\end{array}$ & $\begin{array}{r}257 \\
4\end{array}$ & $\begin{array}{r}321 \\
17\end{array}$ & $\begin{array}{l}40.9 \\
37.6\end{array}$ & $\begin{array}{r}25,350 \\
3,560\end{array}$ & $\begin{array}{r}5,162 \\
923\end{array}$ \\
\hline
\end{tabular}

(1) From the mortality table supplied by the Bureau of Vital Stotistics.

(2) For nonuranium workers, the number is the total years worked by oll of those workers in the two plants studied; for uranium workers, the number is the oc eumulative time periad between submission of the first and last urine somples for uranium analysis. 
A summary of the data is presented in Table 2. This table shows that the ratio of actual deaths to expected deaths (from all causes) is less for uranium workers than for nonuranium workers.

Table 2

SUMMARY RESULTS OF THE STUDY

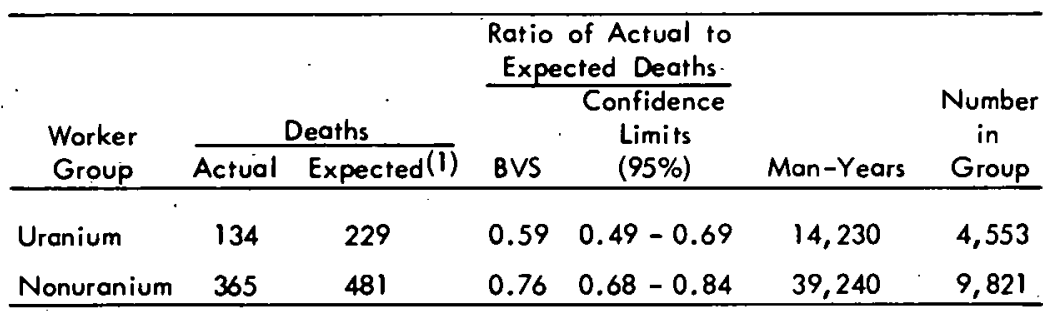

(1) From the mortality table supplied by the Bureau of Vital Statistics.

Complete calculations for this study population were repeated using an annunity table(3) in place of the BVS table to establish the expected deaths. Results showed the same favorable relative mortality experience for uranium workers, compared to nonuranium workers.

Examination of the 1960 Standard Group Mortality Table (4) indicates that if it were used to establish expected deaths, the ratio of actual to expected deaths for the uranium workers would again be significantly less than for nonuranium workers.

The ratio of the number of actual deaths to the number of expected deaths (BVS) for all employees in this study (uranium and nonuranium workers combined) was 0.70 . This same value was found in the previous study, (1) which also included data for the Oak Ridge National Laboratory.

\section{CONCLUSIONS}

A population of over 4,500 employees involving individual uranium work for periods of up to 19 years and a total work time of 14,000 man-years had a more favorable mortality experience than a population of nonuranium workers employed at the same facilities during the same time. Additionally, both groups had a more favorable mortality rate than that predicted on the basis of tables supplied by the Bureau of Vital Statistics.

It is recognized that a number of employee population factors have not been evaluated in this study. Nevertheless, the findings reinforce prior convictions that the goals of safe working conditions are being achieved. 


\section{REFERENCES}

(1) Larson, C. E., Lincoln, T. A., and Bahler, K. W.; Comparison of Mortality of Union Carbide Employees in Oak Ridge Atomic Energy Facilities with US Bureau of Vital Statistics Mortality, K-A-708 (1966).

(2) United States Life Tables: 1959-1961, Public Health Service Publication $1252, \underline{1}(1964)$.

(3) Jenkins, M. J.; "A New Mortality Basis for Annuitants", Transactions of the Acturial Society of America, 1; November 1949.

(4) Commissioners 1960 Standard Group Mortality Table.

(5) McGill, Don; Life Insurance, P 101; Richard D. Irwin, Incorporated, Homewood, Illinois (1964). 


\section{ACKNOWLEDGEMENT}

The authors are indebted to many persons for advice and assistance in making this study. Special gratitude is gratefully expressed to John B. Storer, M.D., W. W. Dotterweich; Barkev Sanders, W. S. Snyder, and Karl Z. Morgan for their review and suggestions; to W. E. Hannan for some mortality data; to Homer R. Gregg and Howard L.: Fore for the electronic data programming and processing; to Robert G. McMillan for statistical assistance; and to $P$. R. Vanstrum for encouragement and counsel in making the study. 


\section{APPENDIX}

\section{SAMPLE CALCULATION FOR EXPECTED DEATHS}

Excerpt from BVS table for white males:

$\begin{array}{cc}\text { Age Interval } & \begin{array}{c}\text { Number Living of Beginning of Age } \\ \text { Interval of 100,000 Born Alive }\end{array} \\ 24-25 & 95,263 \\ 25-26 & 95,106 \\ 26-27 & 94,957 \\ 27-28 & 94,816 \\ 28-29 & 94,679 \\ 29-30 & 94,542 \\ 30-31 & 94,401 \\ 31-32 & 94,254 \\ 32-33 & 94,100 \\ 33-34 & 93,939 \\ 34-35 & 93,769 \\ 35-36 & 93,589 \\ 36-37 & 93,395 \\ 37-38 & 93,185 \\ 38-39 & 92,956 \\ 39-40 & 92,705 \\ 40-41 & 92,427 \\ 41-42 & 92,121\end{array}$

Assume that the population of interest is as follows:

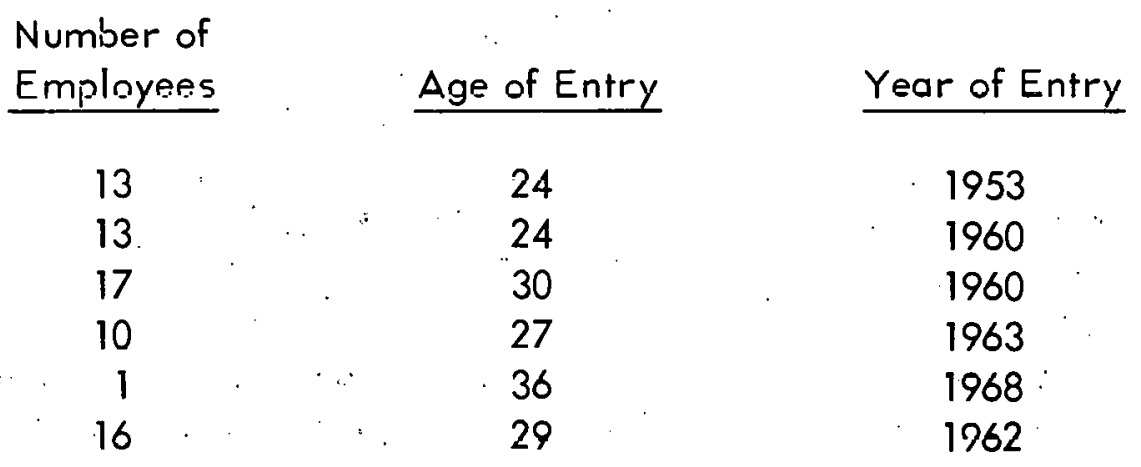


The probability of a 24-year-old employee dying between 1953 and the end of 1969 is calculated as follows:

Value for 24-Year-Old Employees from Table 95,263

Table Value 17 Years Later (that is, when employee is 41) 92,121

Difference

Therefore, in the 17-year period the table predicts 3,142 deaths, or 3.30 percent $(3,142 \div 95,263)$ of those living at the start.

Since there were thirteen 24-year-old employees that entered in 1953, the 0.033 is multiplied by 13 , or:

$0.033 \times 13=0.429$, the expected number of deaths for the thirteen 24-year-old employees who entered in 1953.

For the next group, we have:

$$
\begin{array}{r}
95,263 \\
93,769 \\
\hline 1,494
\end{array}
$$

$1,494 \div 95,263=0.0157$

Therefore, the expected number of deaths is $0.204(0.0157 \times 13)$ for the thirteen 24-year-old employees who entered in 1960.

Similarly, expected deaths for the other groups are:

0.355 for the seventeen 30 -year-olds entering in 1960,

0.110 for the ten 27-year-olds entering in 1963,

0.005 for the one 36-year-old entering in 1968, and

0.230 for the sixteen 29-year-olds entering in 1962.

The sum of all the expected deaths is 1.333 , the expected number of deaths for the considered population.

If different races and sexes were in the group, then the number of living at a given age was taken from the table for the proper race and sex. 